\title{
Cultural Construction of Universities for Undergraduates in Applied Technology
}

\author{
Hua Chai \\ School of Humanities and Media \\ Heihe University \\ Heihe, Heilongjiang, China, 164300
}

\begin{abstract}
College culture has a subtle role in the development of a university, and it is an important part of university core competitiveness. Based on the basic college culture, thinking deeply about the connotation and methods to build college culture in the universities of undergraduates in applied technology from teacher culture, environmental culture, teaching culture, management culture and quality culture etc, which is the urgent need to advance comprehensive strength, and has strong practical direction significance for improving the quality of personnel training, strengthening the connotation of management culture and cultivating their school-running characteristics.
\end{abstract}

Keywords-Applied technology; undergraduate university; college culture; connotation; method

\section{INTRODUCTION}

Development of higher education of China has more than hundred years history, especially in the past decade, Chinese higher education has realized the transformation from elite education to mass education in the rapid development, and has entered the new stage of shifting from "big" to "strong". In this historical turning point, comprehensively improve the quality of education became the actual needs of the development of higher education in China, "Comprehensive improvement" emphasize quality requirements of key colleges and universities and pay attention to the improvement of ordinary colleges. From this point, centered on improving the quality of education, how to grasp the development opportunity, how to meet the challenge, how to explore development of its connotation is an important and urgent task of Technical Applied Undergraduate Universities. In order to adapt to the new development situation, based on the college culture, deeply thinking college culture development of Technical Applied Undergraduate Universities, analyzing its abundant connotation and innovating the development path, making the technical applied undergraduate universities improve personnel training quality, strengthen the management of cultural connotation, cultivate their own characteristics, is of very important practical significance.

College culture has a subtle role on the development of a university, and it is an important part of university core competitiveness. It is the window to show the university image to foreigners and power source for the sustainable development of university. Facing "inherent problems" of the college culture, building the college culture with high quality is a fundamental and strategic task and an important measure to promote the development of its connotation to technical applied undergraduate universities. In the traditional sense, the university cultural development includes three levels, namely material culture, system culture and spiritual culture development. Material culture development focuses on campus building, natural and humanistic landscape, alma mater, media and other tangible carriers of the meaningful symbol function and emphasizes carrying tradition and highlight characteristics; System culture construction takes the pursuit of the modern university system as the core, it emphasize people-orientation and continuous innovation; Construction of spiritual culture pays attention to reveal the university spirit, motivate history tradition of personality, cultivate extensively and enrich the internal quality. Based on the above goals, technical applied undergraduate universities must strengthen the connotation development from the teacher culture, environmental culture, teaching culture, management culture and quality culture dimensions, thinking deeply about the specific connotation of college culture development and implementation approach to adapt to the urgent need of the quality improvement and connotation development.

\section{TO STRENGTHEN THE DEVELOPMENT OF TEACHER Culture, Create The Promotion Space for Teacher DEVELOPMENT}

"College teachers are developed under the influence of the college culture", therefore, strengthening the construction of teacher culture, is the important embodiment of influencing people function of college culture of the technical applied undergraduate universities. Guiding teachers to accept and agree with the unique cultural characteristic centering on university teaching that is different from state organs, enterprises and institutions and research institutes, actively setting up development goals to improve teaching skills, improve their own ability. While complying with strict management regulations, endeavoring to explore innovative and creative ability. Through organized cultural ceremony or cultural activities, creating a loose and harmonious cultural atmosphere, and transforming the external requirements for teachers to the inner conscious centripetal force and cohesive power. To respect the 
requirement of teachers from academic research, classroom teaching, the career planning, etc, taking it as the starting point and the foothold, and coordinating with organizational management target, providing diversified learning resources, constructing platform for open communication and cooperation and creating a persistent development space and a strong culture atmosphere of teachers group. To play teachers' master awareness, leading teachers to think actively and participate in establishment of the school development plan and management system through the democratic management, pushing the development of the individual teacher and the school collective goals conform to each other and generating dynamic "healthy energy".

\section{OPTIMIZE THE CONSTRUCTION OF ENVIRONMENT Culture, ANd Create Poetic AtMosphere OF CONNOTATION DEVELOPMENT}

The technical applied undergraduate universities can optimize the teachers and students learning life space, motivate the teachers and students enterprising spirit that doing scholarly research rigorously and bringing forth new ideas bravely, and creating a soft environment to all kinds of education activity from two aspects of the physical environment and spiritual environment. In terms of physical form, according to actual situations of student's growth and teachers teaching and the concrete connotation of school spirit and the school motto, paying attention to inherit the school tradition and highlight the characteristics of school, optimizing the campus humanities landscape development; At the same time, giving full play to carrier function of "meaning symbols such as the theme cultural activities and campus media, using rich connotation to influence, to cultivate, to inspire and to infect school teachers and students as well as other staff. In terms of spirit form, managers in the education activities must avoid the utilitarian thought and impetuous mentality, on the basis of trusting and respecting teachers, cultivating academic culture soil that benefit to talented people growing, strengthening ethics development through various channels and encouraging teachers and students to create harmonious education environment together that is beneficial to all of them.

\section{TO PROMOTE THE CONSTRUCTION OF TEACHING CUlture, StRENGTHEN THE QUALITY AND FEATURES OF TALENT CULTIVATION}

According to past school-running experience and basis of junior college or the vocational colleges, setting up the culture idea of undergraduate course teaching and regarding it as one of the connotations of college culture construction is rational cognition of the technical applied undergraduate universities to improve education quality. To practice teaching culture development, first of all, highlighting the center position of teaching, actively creating work atmosphere that leaders attach great importance to the teaching, policies focus on teaching, funds guarantee teaching and scientific research promotes teaching, management serves to teaching and supervision escorts teaching and public opinion popularizes teaching. Second, based on culture development, through organizational activities such as learning and communication, training seminars, expert guidance to change managers' and teacher's cognitive theory and practice of undergraduate course teaching, on the basic of the implementation of the specification and operation procedures of undergraduate course teaching, strengthening undergraduate teaching closely based on the talents training goal, improving the cognition level of the discipline and profession, enhancing the ability of professional structure layout adjustment, and formulating effective measures to improve the quality of classroom teaching, enriching the content and methods in the teaching of professional practice, strengthening the teaching management and teaching quality supervision to realize the rapid promotion of undergraduate talent training quality by promoting development of teaching culture in reality. Third, combining the demand for professional talents of regional economic and social development, avoiding "similar" school-running phenomenon, activating their own hematopoietic function, actively exploring teaching culture specific connotation from the personnel training mode, double teachers' cultivation and practical teaching innovation.

\section{TO VAlue the CONSTRUCtion OF MANAGEMENT Culture, Consolidate Center Position of UNDERGRADUATE COURSE TEACHING}

From the development history of the technical applied undergraduate universities, the administrative management must get rid of the fetters of the past management patterns, meet the need of undergraduate education rapidly, stick to teaching as the center, establish the scientific management in the relevant service activities such as education, teaching and academic characteristics to enhance management of cultural connotation and give play to the effectiveness of the management. First, clear service orientation. Set up management institution reasonably, get rid of the administrative bureaucratic. To readjust the management institutions, to avoid the refined classification because of scale expansion and to avoid the waste of education resources and poor communication and coordination because of bloated administrative system. To fully realize that scientific administration is independent and free teaching and serves to scientific research, what it faces is teachers and students full of vigor and vitality. Any administrative departments should respect and follow the rules of education teaching and academic development, meet the needs of teaching and scientific research, truly be responsible for the teaching and scientific research, practically create good space for the school connotation development by administrative management. Second, strengthening management quality, improving management ability and getting rid of the foolishness of administrative management. Faced with new tasks and requirements, the technical applied undergraduate universities must strengthen learning consciousness of administrative people, enhance the quality management and carry out systematic training project with the effective combination of specialization, practicability and demand. To introduce competition mechanism, implement management performance evaluation scientifically, exceed the trivialization of administration. In the implementation of the reform, introduce the competition mechanism into 
administrative management system, make the administrative personnel produces pressure, supervise them to reflect and change their work behaviors through the competition. To establish reasonable assessment and evaluation system, competition should be implemented to the actual administrative work, make the specific power under supervision to ensure the service role of administration. To implement administrative performance evaluation at the same time, combine institutional constraints and humanized incentive effectively, promote administrative personnel selfcontrol ability and realize self improving and self development, finally realizes the transition from experience management and system management gradually to the humanistic management, knowledge management and cultural management, complete modern administrative management mode innovation.

\section{TO HIGHLIGHT THE CONSTRUCTION OF QUALITY} Culture, Promote EduCATION LEVELS to Rise STEAdILY

Quality management is core power for the technical applied undergraduate universities to adhere to the connotation development, to fully examine quality management problems, to innovate implementation methods of quality management, and to strengthen the practice of quality construction and quality improvement. First of all, actively establish the consciousness of quality culture. Quality culture "is a kind of management culture, organizational culture, it has an irreplaceable role in optimizing the university education mode and enhancing core competitiveness, it not only embodies the university's teaching quality, service quality, management, and work quality, but also fully shows the overall quality of a university. Through cultural integration concept, managers and educators should take the quality construction as spontaneous actions, practice quality management activities actively in the education teaching. To break the old path dependence, set up the new view of educational quality, establish new quality management targets, strengthen the design quality, management quality, monitor quality and teaching effect quality in teaching process, adjust and specify all the psychological needs and behavior orientation of teachers' quality. By consciously quality guidance, enhance the quality culture to be permeable, long-term, comprehensive and total, change the quality management conditions; second, to innovate quality management behavior. On the one hand, look at the present situation of the quality management objectively, diagnose effectiveness of quality management methods, inspecting the acceptance of staff's quality management standard the social demand, find holes in quality management, establish quality management behavior goals on this basis. On the other hand, build quality management mode according to the quality management goals, establish main body of quality management such as the administrators, teachers, students and supervisor, set up quality standards and management system, clear the skills and methods of information collection and feedback, etc. To optimize quality management mechanism, base on the enhancement of quality management system, improve work system, management system, evaluation system and rewards and punishment system, value participation, openness and transparency of system construction, establish, improve and implement systems to highlight the quality management consciousness and cohere the spirit of quality management; third, to build scientific management system. On the one hand, base on decision-making and command, quality formation, quality supervision, quality evaluation and feedback, etc to think of the basic quality management system on the whole. Decision-making and command should make the nature of training goals and specifications clear according to school-running, on the basis, scientifically design and develop the talent training scheme and carry out the educational and teaching practice. Quality formation is generated through two-way interactive teaching and learning in the process of talent training, mobilizing the enthusiasm of teachers and students, with teachers' moral quality, professional knowledge and ability accomplishment to promote continuously improvement of students' knowledge and the ability. Quality supervision refers to actively play the supervision and guidance role on talent training through the establishment of supervision organizations at all levels, deeply analyzing problems found during the process, putting forward opinions and suggestions of reference value to managers. Quality evaluation and feedback is to timely feedback the results to examinees during the process of personnel training through integration, analysis, and judgment of all kinds of effective information, perfecting behaviors and increasing efficiency in the education teaching activities. On the other hand, to hold on to and determine the talent training quality standards, implement the talent training scheme and carry out specific parts such as special assessment, clear the basic task of the quality management system in an all-round way. Comprehensively examine school talent training quality standards separately from the country, the industry and school itself, deal with the relationship between basis, orientation and characteristics; Improve rational knowledge of the various departments about the implement of the talent training scheme and respond and cooperate with it actively, try to avoid all kinds of influence factors in the process of operation, ensure smooth and effective implementation of the plan. Aim at the important points such as curricula construction, teachers' teaching and students learning, carry out targeted evaluation, promote curricula construction by curricula evaluation, improve the teaching content and methods by teaching evaluation on teachers, consolidate the effect of learning process by students' academic achievement evaluation, guarantee talent training quality from the "cutting edge" in reality.

\section{REFERENCES}

[1] Jiang Xianping. Boost College Teachers' Development by the Cultural Construction of University [J].research in higher education.2013, (8) : 49-52.

[2] Liu Zhongquan, Xue Guiying, Lan Jueming. Quality Culture: Fundamental for Newly-Established Universities to Promote Their Core Competitiveness; [J].Chinese Adult Education,2009, (16) : 1719. 